\title{
Detection of single nucleotide polymorphisms (SNPs) in HER2, MUC1, ESR1, and BRCA1 genes associated with canine
} mammary cancer

\author{
J. D. Carvajal-Agudelo, L. Giraldo-Chalarca, D. M. Cortes-Mera, \\ P. A. Ossa-López, E. D. Morales-Álvarez and F. A. Rivera-Páez*
}

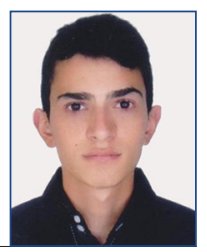

\section{Abstract}

Worldwide, canine mammary cancer (CMC) is the most frequent type of neoplasia in female dogs, and it is three times more frequent in dogs than in humans. In Colombia, CMC is the second most frequent type of cancer, after skin neoplasia. Genetics is one of the most important factors involved in any type of cancer, and the genetic basis of this disease is reflected through line breeding due to changes in allelic frequencies that are traceable using molecular markers. This study aimed to detect single nucleotide polymorphisms (SNPs) associated with CMC in blood samples collected from collected from healthy and CMC female dogs at Diego Villegas Toro Veterinary Hospital of Universidad de Caldas (Manizales, Colombia). We designed primers using PrimerBLAST and Primer3, and gene fragments from HER2, MUC1, ESR1, and BRCA1 were amplified to identify SNPs through genome mapping using the UCSC Genome Institute genome browser. We used the genome of Canis lupus familaris Boxer breed [GCF_000002285.3, (CanFam 3.1)] as a reference to compare the gene fragments and SNPs. We associated SNPs with the CMC and control groups by testing odds ratios (OR) through Fisher's exact tests to determine an association or risk for CMC. We detected two SNPs for ESR1, three for MUC1, six for HER2, and one for BRCA1. MUC1 was the only gene to display an SNP in an exonic region that resulted in an amino acid substitution (Pro $>$ Thr). No significant differences based on the OR were found, though the majority of SNPs, with the exception of four, were found in females with CMC. We report a novel molecular marker for HER2 that amplifies exons 25-26 and introns 24-25, and highlight the importance of conducting further studies on MUC1 and elucidating the role of introns and splicing in candidate genes associated with CMC.

Key words: genetic mapping; genetic variation; intron; mammary neoplasia; SNP association

Juan D. CARVAJAL-AGUDELO, Laura GIRALDO-CHALARCA, Diana M. CORTES-MERA, Paula A. OSSALÓPEZ, Grupo de Investigación GEBIOME, Departamento de Ciencias Biológicas, Facultad de Ciencias Exactas y Naturales, Universidad de Caldas, Calle 65 No. 26-10 Apartado Aéreo 275 Manizales, Caldas, Colombia; Edwin D. MORALES-ÁLVAREZ, Grupo de Investigación GEBIOME, Departamento de Química, Facultad de Ciencias Exactas y Naturales, Universidad de Caldas, Calle 65 No. 26-10 Apartado Aéreo 275 Manizales, Caldas, Colombia; Fredy A. RIVERA-PÁEZ*, (Corresponding author, e-mail: fredy.rivera@ucaldas.edu.co), Grupo de Investigación GEBIOME, Departamento de Ciencias Biológicas, Facultad de Ciencias Exactasay Naturales, Universidad de Caldas, Calle 65 No. 26-10 Apartado Aéreo 275 Manizales, Caldas, Colombia 


\section{Introduction}

Canine mammary cancer (CMC) is the most frequent group of neoplasia in female dogs, with a $50 \%$ to $70 \%$ incidence compared to other types of cancer; it is also three times more prevalent in dogs than in humans (Beselga, 2013; do Carmo Silva et al., 2019). In Colombia, CMC shows a $21.5 \%$ incidence and is second only to skin neoplasia (Caicedo and Acosta, 2012). In Manizales, 25\% of all diagnosed cases of mammary neoplasia are malignant (Pedraza-Ordóñez et al., 2008).

The risk factors, harmful environments, and types and subtypes of CMC have been reported (Araújo et al., 2018). Genetics is one of the most important factors involved in any type of cancer, and is mainly manifested through linebreeding or in dog breeds that are highly susceptible to this disease (Borge et al., 2011). Line breeding causes changes in the allelic frequencies of regulatory genes involved in cancer, which can be studied through genomic markers. They are related to specific changes, such as single nucleotide polymorphisms (SNPs) (Wang and Moult, 2001). SNPs have been associated with changes in hormonal, epidermal, growth, cell differentiation, and cell cycle factors (Ressel et al., 2013; Campos et al., 2015; Hermo et al., 2017). Previous studies on dog breeds, genotype frequency and susceptibility to similar diseases provide efficient models to study the effects of different genes (Borge et al., 2011; Borge et al., 2013). These models imply using direct lines and their progeny, which can be easily studied by non-invasive genotyping through skin or fur scraping and blood samples (Siravegna and Bardelli, 2014).

CMC is poorly characterized at the genomic level, unlike human breast cancer. This is evidenced by the low number of SNPs reported for different genes of interest showing genetic mutations and variations of medical importance (Liu et al., 2014). The main molecular markers and genes reported to date for CMC include estrogen receptors (ESR1), progesterone (PR), epidermal growth (HER2), hormone metabolism [cytochrome P450 (CYP1A1 and CYP1B1)], cellular proliferation [proliferating cell nuclear antigen (PCNA)], cellular regulation [breast cancer 1 and 2 (BRCA1 and BRCA2)], apoptosis [ADP-ribose polymerase (PARP), caspases], and basal [mucin 1 (MUC1) ], among others (Vinothini et al., 2009; Dawood et al., 2011). Many of these genes have important functions in the sustainment of cellular and molecular mechanisms (Borge et al., 2011). Medical diagnosis and the search for molecular markers directly associated with diseases and susceptible genotypes have greatly improved, given the advances in genomic studies (Ginsburg and Willard, 2009; Santillán-Garzón et al., 2015).

The human epidermal growth factor receptor 2 (HER2), also known as erb-b2 (receptor tyrosine kinase 2), is widely used as a molecular marker for mammary cancer prognosis in dogs and humans (Muhammadnejad et al., 2012). Furthermore, SNPs of HER2 related to CMC have been reported (Hsu et al., 2009; Canadas-Sousa et al., 2019a). Likewise, BRCA1 is used as a diagnostic molecular marker and is directly associated with tumour suppression and cell cycle regulation (Tsuchida Complete et al., 2001; Rivera et al., 2009; Enginler et al., 2014; Sun et al., 2015). Other molecular markers, such as estrogen receptor alpha (ESR1), are mediators of hormonal processes and can promote carcinogenic responses (Russo and Russo, 2008). Therefore, the direct relationship of these genes with regulatory mechanisms in mammary tissue has motivated the study of SNPs associated with CMC (Borge et al., 2013; Akis et al., 2019). MUC1 is involved in apoptotic responses 
in tumour cells (Yin et al., 2003) and is considered a carcinogenic gene related to breast cancer in humans (De Cremoux et al., 2000; Kufe, 2013).

Several studies on SNP identification report mutations that can cause significant alterations in cellular function of candidate genes and, thus, could be used as molecular markers for cancer prognosis or diagnosis. This study aimed to detect SNPs of HER2, MUC1, ESR1, and BRCA1 genes in patients with CMC in Manizales (Caldas, Colombia).

\section{Materials and methods}

\section{Sample collection}

We studied 31 cases of female dogs at Diego Villegas Toro Veterinary Hospital of Universidad de Caldas (Manizales, Colombia) between June 2018 and January 2019. Nineteen patients showed alterations in mammary glands and 12 were healthy patients (control group). We collected 4 $\mathrm{mL}$ of peripheral blood from each patient in $5 \mathrm{~mL}$ heparin tubes through aseptic venipuncture and immediately conserved the samples at $-4{ }^{\circ} \mathrm{C}$.

\section{Amplification of HER2, MUC1, ESR1, and BRCA1}

Genomic DNA was isolated from blood samples using the DNeasy Blood and Tissue Kit (Qiagen ${ }^{\circledR}$ ) following the manufacturer's instructions. We assessed DNA quality by $1 \%$ agarose gel electrophoresis and estimated the amount of DNA through fluorometric quantification on a Quantus Fluorometer ${ }^{\mathrm{TM}}$ (Promega ${ }^{\circledR}$ ) using the QuantiFluor ${ }^{\circledR}$ dsDNA System (Promega ${ }^{\circledR}$ ).

We searched the literature for primers used to analyse polymorphic sites in MUC1, ESR1, and BRCA1 (Table 1). For HER2, we designed primers using Primer-BLAST and Primer3 (Untergasser et al., 2012; Ye et al., 2012) and analysed the primers using Oligoanalyzer (IDT Integrated DNA Technologies). Primers were evaluated with conventional PCR on a Techne TC-PLUS thermocycler. We used a final volume per reaction of $40 \mu \mathrm{L}$, containing $20.6 \mu \mathrm{L}$ ultrapure water, $8 \mu \mathrm{L}$ 5X buffer, $2.4 \mu \mathrm{L} \mathrm{MgCl}_{2}(25 \mathrm{mM}), 3.2 \mu \mathrm{L}$ dNTPs mix $(10 \mathrm{mM}), 0.6 \mu \mathrm{L}$ each primer $(25 \mu \mathrm{M}), 2$ units GoTaq ${ }^{\circledR}$ Flexi DNA Polymerase (Promega ${ }^{\circledR}$ ), and $4 \mu \mathrm{L}$ DNA. The thermal cycling conditions were initial denaturation at $95^{\circ} \mathrm{C}$ for $5 \mathrm{~min}$, followed by 35 cycles at $95^{\circ} \mathrm{C}$ for $20 \mathrm{~s}, 55^{\circ} \mathrm{C}$ for $15 \mathrm{~s}, 72^{\circ} \mathrm{C}$ for $30 \mathrm{~s}$, and a final extension at $72{ }^{\circ} \mathrm{C}$ for $7 \mathrm{~min}$. PCR products were separated by horizontal electrophoresis on $1 \%$ agarose gels using TBE $1 \mathrm{X} \mathrm{pH} 8.0$ running buffer at $100 \mathrm{v} / 40 \mathrm{~mA}$. Gels were stained with $\mathrm{SYBR}^{\circledR}$ Safe and visualized on a Gel Doc-It2 310 photodocumenter (UVP). Amplicons were purified using

Table 1. Primers used for the detection of SNPs of each gene and amplification characteristics.

\begin{tabular}{|c|c|c|c|c|c|}
\hline $\begin{array}{l}\text { Gen } \\
\text { name }\end{array}$ & Primer & $\begin{array}{c}\text { Annealing } \\
\text { temperature }\end{array}$ & $\begin{array}{l}\text { Amplicon } \\
\text { size (pb) }\end{array}$ & $\begin{array}{l}\text { Gen } \\
\text { region }\end{array}$ & Reference \\
\hline HER2 & $\begin{array}{l}\text { F 5'-ATTCTCACGTATGGCCAGGG-3' } \\
\text { R 5'-GGACCCATTTCCTGCCTCATC-3' }\end{array}$ & $59^{\circ} \mathrm{C}$ & 1200 & $\begin{array}{c}\text { Exon } 25, \\
26 \text { Intron } \\
24,25\end{array}$ & This study \\
\hline MUC1 & $\begin{array}{l}\text { F 5' -CTGCTGGTGCTGGTCTGTGTTCTG-3' } \\
\text { R 5'-GGCTGCTGGGTTCGGGTTCAT-3' }\end{array}$ & $59^{\circ} \mathrm{C}$ & 1200 & $\begin{array}{l}\text { Exon } 7 \\
\text { Intron } 6\end{array}$ & $\begin{array}{l}\text { (Ishiguro } \\
\text { et al., 2007) }\end{array}$ \\
\hline BRCA1 & $\begin{array}{l}\text { F 5' -TAGAGGGTCCAGGTCAAGTG-3' } \\
\text { R 5'-ACAGGTACACCATCTACTCC-3' }\end{array}$ & $56^{\circ} \mathrm{C}$ & 680 & $\begin{array}{c}\text { Exon } 20 \\
21 \text { Intron } \\
20,21\end{array}$ & $\begin{array}{l}\text { (Qiu \& Lin, } \\
\text { 2016) }\end{array}$ \\
\hline ESR1 & $\begin{array}{l}\text { F 5' -ACCACTCTTCACTGCCACTAACTC-3' } \\
\text { R 5' - TACTCTTTCCСCTGTCTTCCTAAT-3' }\end{array}$ & $55^{\circ} \mathrm{C}$ & 320 & Intron 6 & $\begin{array}{l}\text { (Pathirana } \\
\text { et al., 2010) }\end{array}$ \\
\hline
\end{tabular}


the Wizard ${ }^{\circledR}$ SV Gel and PCR CleanUp System (Promega ${ }^{\circledR}$ ), according to the manufacturer's instructions. Sanger sequencing of the purified amplicons was provided by Macrogen (South Korea). Sequence quality was assessed using Geneious Trial v8.14 (Drummond et al., 2009 and GeneStudio V.2.2 (GeneStudio Inc, 2011).

\section{Identity, specificity, and genetic mapping of SNPs}

The reference gene sequences for HER2, MUC1, ESR1, and BRCA1 were obtained from the genome of Canis lupus familaris Boxer breed [GCF_000002285.3, (CanFam 3.1)]. We mapped each gene to the genome using the BLAT tool (Kent, 2002) of the UCSC Genome Institute genome browser (https://genome.ucsc. edu/) (Karolchik et al., 2003) to compare SNPs and confirm their location and identity. Genomic locations and reference sequences for each gene are shown in Table 2. The sequences generated in this study were aligned to the reference sequences using ClustalW in MEGA $X$ (Kumar et al., 2018).

\section{Data analysis}

To determine significant differences between the SNPs and tumour presence, we associated SNPs with the CMC and control groups by testing odds ratios
(OR) using Fisher's exact tests. We used a statistical significance level of 0.05 . The analyses were conducted using IBM SPSS (Arbuckle, 2011).

\section{Results}

Of the 31 patients included in the study, 51.6\% were purebred (e.g., Boston Terrier, English Bulldog, Border Collie, French Poodle, Labrador Retriever, Pinscher, Pitbull, Samoyed, Schnauzer, and Shih Tzu) and $48.4 \%$ were mixedbreed. The DNA sequences obtained for each patient were compared to ESR1, MUC1, HER2, and BRCA1 reference gene sequences from the genome of Canis lupus familiaris Boxer breed [GCF_000002285.3, (CanFam 3.1)]. The alignments showed identities equal to or greater than $99 \%$. Furthermore, we detected two SNPs for ESR1, three of MUC1, six of HER2, and one for BRCA1, as well as two deletions for MUC1 and three deletions of ESR1 (Table 3). The GenBank accessions for the nucleotide sequences obtained in this study are [MT552115-MT552145] for HER2, [MT550815-MT550843] for ESR1, [MT561299-MT561329] for BRCA1, and [MT571366-MT571396] for MUC1.

The association analysis of SNPs with $\mathrm{CMC}$ and control patients did not show significant differences for any SNP. The OR did not indicate a direct significant

Table 2. Candidate genes for SNP detection and genomic locations using the reference genome of Canis lupus familiaris [GCF_000002285.3 (CanFam 3.1)].

\begin{tabular}{|c|c|c|c|c|c|}
\hline $\begin{array}{c}\text { Gen } \\
\text { name }\end{array}$ & Chromosome & Localization range & $\begin{array}{c}\text { Number } \\
\text { of exons }\end{array}$ & $\begin{array}{c}\text { Access number } \\
\text { [GenID] }\end{array}$ & Encode to \\
\hline ESR1 & 1 & $42081969-42368544$ & 10 & NC_006583.3 [403640] & $\begin{array}{c}\text { Estrogen receptor } \\
\text { alpha }\end{array}$ \\
\hline HER2 & 9 & $22760373-22785367$ & 27 & NC_006591.3 [403883] & $\begin{array}{c}\text { Receptor tyrosine- } \\
\text { protein kinase } \\
\text { erbB-2 }\end{array}$ \\
\hline MUC1 & 7 & $42340375-42344690$ & 8 & NC_006589.3 [448784] & Mucin 1 \\
\hline BRCA1 & 9 & $19958941-20025494$ & 22 & NC_006591.3 [403437] & $\begin{array}{c}\text { Breast cancer type } \\
\text { 1 susceptibility } \\
\text { protein }\end{array}$ \\
\hline
\end{tabular}


Table 3. Detected SNPs and indels and their location and group (CMC patient or control) in the study genes using the reference genome of Canis lupus familiaris [GCF_000002285.3 (CanFam 3.1)].

\begin{tabular}{|c|c|c|c|c|c|c|c|c|c|}
\hline $\begin{array}{c}\text { Gen } \\
\text { name }\end{array}$ & \# SNPs & $\begin{array}{c}\text { Gen } \\
\text { region }\end{array}$ & Alelle & $\begin{array}{l}\text { Local- } \\
\text { ization }\end{array}$ & Dog breed & Group & $\begin{array}{l}\text { Indels } \\
\text { región }\end{array}$ & $\begin{array}{c}\text { Indels } \\
\text { reference }\end{array}$ & $\begin{array}{l}\text { Indels } \\
\text { localiza- } \\
\text { tion }\end{array}$ \\
\hline \multirow{9}{*}{ HER2 } & \multirow{6}{*}{6} & \multirow{2}{*}{ Intron 24} & \multirow{2}{*}{$\mathrm{T} / \mathrm{G}$} & \multirow{2}{*}{23009} & Shitzu & CMC & & & \\
\hline & & & & & Pincher & CMC & & & \\
\hline & & Intron 24 & $\mathrm{~T} / \mathrm{G}$ & 23078 & French Poodle & Control & & & \\
\hline & & \multirow{3}{*}{ Intron 24} & \multirow{3}{*}{$\mathrm{A} / \mathrm{T}$} & \multirow{3}{*}{23095} & Mixed-breed & CMC & & & \\
\hline & & & & & French Poodle & CMC & & & \\
\hline & & & & & Pincher & CMC & & & \\
\hline & & Intron 25 & $\mathrm{C} / \mathrm{G}$ & 23304 & Boston Terrier & CMC & & & \\
\hline & & Intron 25 & $\mathrm{G} / \mathrm{C}$ & 23399 & Boston Terrier & CMC & & & \\
\hline & & Intron 25 & $C / G$ & 23427 & Boston Terrier & CMC & & & \\
\hline \multirow[t]{3}{*}{ MUC1 } & \multirow[t]{3}{*}{3} & Intron 6 & $\mathrm{C} / \mathrm{A}$ & 4243 & Shitzu & CMC & Intron 6 & $-/ G$ & 4250 \\
\hline & & Intron 6 & $\mathrm{C} / \mathrm{A}$ & 4301 & Mixed-breed & Control & Intron 6 & $-/ A$ & 4263 \\
\hline & & Exon 7a & $\mathrm{G} / \mathrm{C}$ & 4451 & Mixed-breed & CMC & & & \\
\hline \multirow{6}{*}{ ESR1 } & \multirow{4}{*}{2} & \multirow{4}{*}{ Intron 6} & \multirow{4}{*}{$\mathrm{T} / \mathrm{C}$} & \multirow{4}{*}{67395} & Mixed-breed & Control & \multirow{4}{*}{ Intron 6} & \multirow{4}{*}{$-/ \mathrm{T}$} & \multirow{4}{*}{67581} \\
\hline & & & & & English Bulldog & CMC & & & \\
\hline & & & & & Collie & CMC & & & \\
\hline & & & & & Mixed-breed & Control & & & \\
\hline & & Intron 6 & $\mathrm{C} / \mathrm{G}$ & 67282 & Mixed-breed & $\mathrm{CMC}$ & Intron 6 & $-/ G$ & 67588 \\
\hline & & & & & & & Intron 6 & $-/ A$ & 67593 \\
\hline BRCA1 & 1 & Intron 21 & $\mathrm{C} / \mathrm{T}$ & 63970 & Mixed-breed & CMC & & & \\
\hline
\end{tabular}

${ }^{a}$ non-synonymous SNP located in position 1 of the codon, amino acid substitution Pro>Thr in position 1415 of the protein.

association with CMC since only three SNPs (4451 C>A MUC1, 23079 T>G HER2, 67395 ESR1 T>C) were found within the risk interval $(>1)$ (Table 4$)$. However, the majority of SNPs, with the exception of four, were detected in female dogs with CMC.

\section{Discussion}

This study involves SNPs in exons 25 and 26 of HER2 and identifies unique SNPs in introns 24 and 25. Previous studies have identified SNPs of HER2 associated with CMC in exons 14-18 (Hsu et al., 2009) and 9, 13, 14, 16, 23, and 27
(Borge et al., 2011). These results suggest that most SNPs of HER2 related to CMC are located along the gene and not in certain regions. For ESR1, we found two novel SNPs in intron 6, while prior studies have only assessed exons 2, 4, and 8 in relation to CMC (Borge et al., 2011). Borge et al. (2013) and Canadas-Sousa et al. (2019b) genotyped and haplotyped HER2, finding extensive and strong relationships along the entire gene.

For BRCA1, we report one SNP in intron 21. BRCA1 is one of the most studied genes in CMC. Previous studies analysing exon 9, intron 8, 5' UTR (Enginler et al., 2014), exon 22 (Borge et al., 2011), 5' 
Table 4. Risk analysis based on odds ratios (OR) for SNPs detected in controls and patients with canine mammary cancer.

\begin{tabular}{|c|c|c|c|c|c|c|}
\hline $\begin{array}{c}\text { SNP } \\
\text { localization }\end{array}$ & $\begin{array}{c}\text { Gen } \\
\text { name }\end{array}$ & Alelle & CMC (\%) & Control $(\%)$ & P-value & OR $(95 \%)$ \\
\hline \multirow{2}{*}{4451} & \multirow{2}{*}{ MUC1 } & G & $1(5.3 \%)$ & $0(0 \%)$ & \multirow{2}{*}{0.613} & \multirow{2}{*}{0.947 (0.852-1.053) } \\
\hline & & C & $18(94.7 \%)$ & $12(100 \%)$ & & \\
\hline \multirow{2}{*}{4243} & \multirow{2}{*}{ MUC1 } & C & $1(5.3 \%)$ & $0(0 \%)$ & \multirow{2}{*}{0.613} & \multirow{2}{*}{0.947 (0.852-1.053) } \\
\hline & & A & $18(94.7 \%)$ & $12(100 \%)$ & & \\
\hline \multirow{2}{*}{4301} & \multirow{2}{*}{ MUC1 } & C & $0(0 \%)$ & $1(8.3 \%)$ & \multirow{2}{*}{0.387} & \multirow{2}{*}{$1.091(0.920-1.294)$} \\
\hline & & A & $19(100 \%)$ & $11(91.7 \%)$ & & \\
\hline \multirow{2}{*}{67282} & \multirow{2}{*}{ ESR1 } & C & $1(5.3 \%)$ & $0(0 \%)$ & \multirow{2}{*}{0.613} & \multirow{2}{*}{0.947 (0.852-1.053) } \\
\hline & & G & $18(94.7 \%)$ & 12 (100\%) & & \\
\hline \multirow{2}{*}{67395} & \multirow{2}{*}{ ESR1 } & $T$ & $2(10.5 \%)$ & $2(16.7 \%)$ & \multirow{2}{*}{0.507} & \multirow{2}{*}{$1.074(0.798-1.444)$} \\
\hline & & C & $17(89.5 \%)$ & $10(83.3 \%)$ & & \\
\hline \multirow{2}{*}{23009} & \multirow{2}{*}{ HER2 } & T & $2(10.5 \%)$ & 0 (0\%) & \multirow{2}{*}{0.368} & \multirow{2}{*}{$0.895(0.767-1.044)$} \\
\hline & & G & 17 (89.5\%) & $12(100 \%)$ & & \\
\hline \multirow{2}{*}{23078} & \multirow{2}{*}{ HER2 } & $\mathrm{T}$ & $0(0 \%)$ & 1 (8.3\%) & \multirow{2}{*}{0.387} & \multirow{2}{*}{$1.091(0.920-1.294)$} \\
\hline & & G & $19(100 \%)$ & 11 (91.7\%) & & \\
\hline \multirow{2}{*}{23095} & \multirow{2}{*}{ HER2 } & A & $3(15.8 \%)$ & $0(0 \%)$ & \multirow{2}{*}{0.216} & \multirow{2}{*}{$0.842(0.693-1.023)$} \\
\hline & & T & $16(84.2 \%)$ & $12(100 \%)$ & & \\
\hline \multirow{2}{*}{23304} & 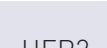 & C & $1(5.3 \%)$ & 0 (0\%) & $0<12$ & 0 \\
\hline & HERL & G & $18(94.7 \%)$ & $12(100 \%)$ & 0.613 & $0.947[0.852-1.053]$ \\
\hline 23200 & HER? & G & $1(5.3 \%)$ & 0 (0\%) & 0613 & $0 / 7(052-10521$ \\
\hline 23399 & ПЕЕКL & C & 18 (94.7\%) & $12(100 \%)$ & 0.013 & $0.94 /(0.032-1.053)$ \\
\hline 20/27 & 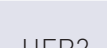 & C & $1(5.3 \%)$ & 0 (0\%) & $0<1$ & $00 / 710.052$ \\
\hline$\angle 34 \angle 1$ & ПЕЕRL & G & 18 (94.7\%) & $12(100 \%)$ & 0.013 & $0.94 /(0.032-1.003)$ \\
\hline 63970 & $\mathrm{BR} \cap \wedge 1$ & C & $1(5.3 \%)$ & $0(0 \%)$ & 0,613 & 0 \\
\hline $034 / 0$ & BRCAI $\longrightarrow>$ & $\mathrm{T}$ & 18 (94.7\%) & $12(100 \%)$ & 0.613 & $0.94 /[0.852-1.053]$ \\
\hline
\end{tabular}

flanking region (Qiu and Lin 2016), and 5'/ 3' UTRs (Sun et al., 2015), and array genotyping studies on BRCA1 (Rivera et al., 2009) found strong associations with the incidence and development of $\mathrm{CMC}$. Consequently, research on this gene requires studying a wide region for association analyses. For MUC1, there are no SNP association studies in CMC; therefore, this is the first study to characterize SNPs of MUC1 in exon 7 and intron 6 in $\mathrm{CMC}$ research. We report three SNPs for MUC1, specifically, one result- ing in an amino acid substitution (4451 G/C, Pro/Thr). Other studies have found a relationship between the expression of MUC1 and CMC (Campos et al., 2015), and associated SNPs in humans (Zeillinger et al., 2000; Yang et al., 2007). These previous findings suggest that this gene strongly influences molecular mechanisms in CMC, which must be further studied in canine models. Finally, we report two deletions of MUC1 and three of ESR1 in intronic regions, which could be used to curate the sequences of the 
corresponding genes in the reference genome of Canis lupus familaris Boxer breed [GCF_000002285.3, (CanFam 3.1)].

The main challenges of studying specific candidate genes involved in diseases include the information obtained from these genes and coverage; the latter is limited by the design of molecular markers and, therefore, restricts the information and relationships that can be found (Thomas et al., 2009). SNP association studies in $\mathrm{CMC}$ have focused on exonic regions since these show direct changes in amino acid composition (Borge et al., 2011; Goebel and Merner, 2017). However, intronic SNPs can induce excisions and alternative splicing, promote changes in RNA stability or structure that directly affect gene expression, interfere with the speed and accuracy of transcription and/ or translation, and alter protein folding (Canadas-Sousa et al., 2019a). Moreover, the use of any gene involved in the etiopathogenesis of a disease should be supported by a significant association at the population level and/or experimental demonstration (Wang and Moult, 2001).

In this context, all SNPs detected in this study are novel, since the majority are located in intronic regions and these SNPs are not generally studied. However, studies on SNPs in intronic regions are relevant since induced changes in excisions, splicing, and gene expression can significantly alter the phenotype and influence cancer development (Hiratani et al., 2005; Law et al., 2007). Moreover, we report a new marker of HER2 that amplifies exons 25-26 and introns 24-25, which can be promising for future studies on CMC.

\section{Acknowledgments}

To the Vice-rectory of Research and Post-graduate Studies of Universidad de Caldas for funding the project titled "Expression of ER- $\alpha$, MUC1, HER-2 genes and their signficance in the early diagnosis of canine mammary cancer in Manizales, Caldas" (Expresión de los genes ER- $\alpha$, MUC1, HER-2 y su significancia en el diagnóstico temprano en cáncer mamario canino en Manizales, Caldas) code 0298218. To the research group GEBIOME and Diego Villegas Toro Veterinary Hospital of Universidad de Caldas for their contributions to the project.

\section{References}

1. AKIS, I., S. O. ENGINLER, K. OZTABAK, D. HAKTANIR, G. ATMACA and N. H. CAKMAK (2019): Partial sequencing of ESR1 and CDK5RAP2 genes in dogs with mammary tumours. Ind. J. Anim. Res. 54, 729-733.

2. ARAÚJO, P. B., D. S. PEREIRA-CAMPINHO, D. M. F. SILVA, D. N. A., GONÇALVES, F. S. MENDONÇA, F. A. L. SOUZA and J. EVÊNCIONETO (2018): Influência da neoplasia mamária na concentração sérica de hormônios e na expressão de receptores de estrógeno e progesterona em cadelas. Pesqui. Vet. Brasil. 38, 949-956.

3. ARBUCKLE, J. L. (2011): IBM SPSS Amos 20 user's guide. Amos Development Corporation, SPSS Inc.

4. BESELGA, A. G. (2013): Avaliação da expressão do recetor HER-2 em carcinomas mamários caninos. Dissertation. Faculdade de Medicina Veterinária, Universidade de Lisboa.

5. BORGE, K. S., A. L. BØRRESEN-DALE and F. LINGAAS (2011): Identification of genetic variation in 11 candidate genes of canine mammary tumour. Vet. Comp. Oncol. 9, 241-250.

6. BORGE, K. S., M. MELIN, P. RIVERA, S. I. THORESEN, M. T. WEBSTER, H. VON EULER, K. LINDBLAD-TOH and F. LINGAAS (2013): The ESR1 gene is associated with risk for canine mammary tumours. BMC Vet. Res. 9, 69.

7. CAICEDO, J. A., C. A. IREGUI, M. E. CABARCAS and B. J. ACOSTA (2012): Estudio comparativo de la frecuencia de tumores mamarios según sexo, edad y tipo histológico en caninos y humanos en los laboratorios de patología anatómica de la Universidad Nacional de Colombia sede Bogotá. Revista Colombiana de Ciencia Anim. 5(1).

8. CAMPOS, L. C., SILVA, J. O., SANTOS, F. S., ARAÚJO, M. R., LAVALLE, G. E., FERREIRA, E., and CASSALI, G. D. (2015): Prognostic significance of tissue and serum HER2 and MUC1 in canine mammary cancer. J. Vet. Diag. Invest. 27, 531-535.

9. CANADAS-SOUSA, A., M. SANTOS, R. MEDEIROS and P. DIAS-PEREIRA (2019a): Single Nucleotide Polymorphisms Influence Histological Type and Grade of Canine Malignant Mammary Tumours. J. Comp. Pathol. 172, 72-79.

10. CANADAS-SOUSA, A., M. SANTOS, B. LEAL, R. MEDEIROS and P. DIAS-PEREIRA (2019b): Estrogen receptors genotypes and canine mammary neoplasia. BMC Vet. Res. 15, 325.

11. DAWOOD, S., R. HU, M. D. HOMES, L. C. COLLINS, S. J. SCHNITT, J. CONNOLLY, G. A. COLDITZ R. M. and TAMIMI (2011): Defining breast cancer prognosis based on molecular phenotypes: results from a large cohort study. Breast Cancer Res. Treat. 126, 185-192. 
12. DE CREMOUX, P., J. M. EXTRA, M. G. DENIS, J. Y. PIERGA, E. BOURSTYN, C. NOS, K. B. CLOUGH, E. BOUDOU, E. C. MARTIN and A. MÜLLER (2000): Detection of MUC1-expressing mammary carcinoma cells in the peripheral blood of breast cancer patients by real-time polymerase chain reaction. Clin. Cancer Res. 6, 3117-3122.

13. DO CARMO SILVA, H., A. R. DE OLIVEIRA, R. DOS SANTOS HORTA, A. C. R., MERÍSIO, B. V. DE SENA, M. C. C. DE SOUZA and M. C. FLECHER (2019): Epidemiology of canine mammary gland tumours in Espírito Santo, Brazil. Acta Sci. Vet. 47.

14. DRUMMOND, A. J., B. ASHTON, M. CHEUNG, J. HELED, M. KEARSE, R. MOIR, S. STONESHAVAS, S. STURROCK, T. THIERER and A. WILSON (2009): Geneious v4.6. In http://www. geneious.com.

15. ENGINLER, S. O., I. AKIŞ, T. S. F. TOYDEMIR, K. OZTABAK, D. HAKTANIR, M. C. GÜNDÜZ, I KIRŞAN and I. FIRAT (2014): Genetic variations of BRCA1 and BRCA2 genes in dogs with mammary tumours. Vet. Res. Commun. 38, 21-27.

16. GENESTUDIO INC. (2011): GeneStudio Professional Software. http://genestudio.com/

17. GINSBURG, G. S. and H. F. WILLARD (2009): Genomic and personalized medicine: foundations and applications. Translational Res. 154, 277-287

18. GOEBEL, K. and N. D. MERNER (2017): A monograph proposing the use of canine mammary tumours as a model for the study of hereditary breast cancer susceptibility genes in humans. Vet. Med. Sci. 3, 51-62.

19. HERMO, G. A., M. G. GARCIA, P. A. TORRES and M. C. GOBELLO (2017): Tumores de mama en la perra. Ciencia Vet. 7, 1-25.

20. HIRATANI, H., BOWDEN, D. W., IKEGAMI, S., SHIRASAWA, S., SHIMIZU, A., IWATANI, Y., and AKAMIZU, T. (2005): Multiple SNPs in intron 7 of thyrotropin receptor are associated with Graves' disease. J. Clin. Endocrinol. Metabol. 90, 2898-2903.

21. HSU, W.-L., H.-M. HUANG, J.-W. LIAO, M.L. WONG and S.-C. CHANG (2009): Increased survival in dogs with malignant mammary tumours overexpressing HER-2 protein and detection of a silent single nucleotide polymorphism in the canine HER-2 gene. Vet. J. 180, 116-123.

22. ISHIGURO, K., E. BABA, R. TORII, H. TAMADA N. KAWATE, S. HATOYA, V. WIJEWARDANA, D. KUMAGAI, K. SUGIURA and T. SAWADA (2007): Reduction of mucin-1 gene expression associated with increased Escherichia coli adherence in the canine uterus in the early stage of dioestrus. Vet. J. $173,325-332$.

23. KAROLCHIK, D., R. BAERTSCH, M. DIEKHANS, T. S. FUREY, A. HINRICHS, Y. T. LU, K. M. ROSKIN, M. SCHWARTZ, C. W. SUGNET and D. J. THOMAS (2003): The UCSC genome browser database. Nucleic Acids Res. 31, 51-54.

24. KENT, W. J. (2002): BLAT-the BLAST-like alignment tool. Gen. Res. 12, 656-664.

25. KUFE, D. W. (2013): MUC1-C oncoprotein as a target in breast cancer: activation of signaling pathways and therapeutic approaches. Oncogene 32, 1073-1081.

26. KUMAR, S., G. STECHER, M. LI, C. KNYAZ and K. TAMURA (2018): MEGA X: molecular evolutionary genetics analysis across computing platforms. Mol. Biol. Evol. 35, 1547-1549.

27. LAW, A. J., J. E. KLEINMAN, D. R. WEINBERGER and C. S. WEICKERT (2007): Disease-associated intronic variants in the ErbB4 gene are related to altered ErbB4 splice-variant expression in the brain in schizophrenia. Human Mol. Genet. 16, 129-141.

28. LIU, D., H. XIONG, A. E. ELLIS, A. E., NORTHRUP, N. C., RODRIGUEZ, C. O., O'REGAN, R. M., DALTON, S., and ZHAO, S. (2014): Molecular homology and difference between spontaneous canine mammary cancer and human breast cancer. Cancer Res. 74, 5045-5056.

29. MUHAMMADNEJAD, A., E. KEYHANI, P. MORTAZAVI, F. BEHJATI and I. S. HAGHDOOST (2012): Overexpression of HER-2/neu in Malignant Mammary Tumors: Translation of Clinicopathological Features from Dog to Human. Asian Pac. J. Cancer Prev. 13, 6415-6421.

30. PATHIRANA, I. N., K. TANAKA, N. KAWATE, M. TSUII, K. KIDA, S. HATOYA, T. INABA and H. TAMADA (2010): Analysis of single nucleotide polymorphisms in the 3'region of the estrogen receptor 1 gene in normal and cryptorchid Miniature Dachshunds and Chihuahuas. J. Reprod. Devel. 1004260268.

31. PEDRAZA-ORD'ONEZ, F. J., G. FERREIRA-DE-LACUESTA and S. M. MURILLO-MENJURA (2008): Análisis retrospectivo de 124 casos de neoplasia mamaria en caninos de la ciudad de Manizales. Veterinaria y Zootecnia, Universidad de Caldas.

32. QIU, H. and D. LIN (2016): Roles of DNA mutation in the coding region and DNA methylation in the 5 ' flanking region of BRCA1 in canine mammary tumors. J. Vet. Med. Sci. 78, 943-949.

33. RESSEL, L., R. PULEIO, G. R. LORIA, I. VANNOZZI, F. MILLANTA, S. CARACAPPA and A. POLI (2013): HER-2 expression in canine morphologically normal, hyperplastic and neoplastic mammary tissues and its correlation with the clinical outcome. Res. Vet. Sci. 94, 299-305.

34. RIVERA, P., M. MELIN, T. BIAGI, T. FALL, J. HÄGGSTRÖM, K. LINDBLAD-TOH and H. VON EULER (2009): Mammary tumor development in dogs is associated with BRCA1 and BRCA2. Cancer Res. 69, 8770-8774.

35. RUSSO, J. and I. H. RUSSO (2008): Breast development, hormones and cancer. In Innovative Endocrinology of Cancer (52-56).

36. SANTILLÁN-GARZÓN, S., D. DIEGO-ÁLVAREZ, C. BUADES, A. ROMERA-LÓPEZ, L. PÉREZCABORNERO, D. VALERO-HERVÁS, D. CANTALAPIEDRA, V. FELIPE-PONCE, G. HERNÁNDEZ-POVEDA and M. J. ROCA (2015): Diagnóstico molecular de enfermedades genéticas: del diagnóstico genético al diagnóstico genómico con la secuenciación masiva. Rev. Méd. Clín. Las Condes 26, 458-469.

37. SIRAVEGNA, G., and BARDELLI, A. (2014): Genotyping cell-free tumor DNA in the blood to detect residual disease and drug resistance. Gen. Biol. 15, 449.

38. SUN, W., X. YANG, H. QIU, D. ZHANG, H. WANG, J. HUANG and D. LIN (2015): Relationship between three novel SNPs of BRCA1 and canine mammary tumors. J. Vet. Med. Sci. 77, 1541-1543.

39. TAYLOR-PAPADIMITRIOU, J., J. BURCHELL, D. W. MILES and M. DALZIEL (1999): MUC1 and cancer. Biochim Biophys Acta (BBA)-Mol. Basis Dis. 1455, 301-313.

40. THOMAS, D. C., G. CASEY, D. V. CONTI, R. W HAILE, J. P. LEWINGER and D. O. STRAM (2009): Methodological issues in multistage genome-wide association studies. Statistical Science: A Review 
Journal of the Institute of Mathematical Statistics, 24, 414 .

41. TSUCHIDA, S., S. IKEMOTO and M. TAGAWA (2001): Microsatellite polymorphism in intron 14 of the canine BRCA1 gene. J. Vet. Med. Sci. 63, 479-481.

42. UNTERGASSER, A., I. CUTCUTACHE, T. KORESSAAR, J. YE, B. C. FAIRCLOTH, M. REMM S. G. and ROZEN (2012): Primer3-new capabilities and interfaces. Nucleic Acids Res. 40, e115-e115.

43. VINOTHINI, G., C. BALACHANDRAN and S. NAGINI (2009): Evaluation of molecular markers in canine mammary tumors: correlation with histological grading. Oncology Research Featuring Preclinical and Clinical Cancer Therapeutics 18, 193-201.

44. WANG, Z. and J. MOULT (2001): SNPs, protein structure, and disease. Hum. Mutation 17, 263-270.

45. YANG, E., X. F. HU P. X. and XING (2007) Advances of MUC1 as a target for breast cancer immunotherapy. Histol. Histopathol. 22, 905-922.

46. YE, J., G. COULOURIS, I. ZARETSKAYA, I CUTCUTACHE, S. ROZEN and T. L. MADDEN (2012): Primer-BLAST: a tool to design targetspecific primers for polymerase chain reaction. BMC Bioinformatics 13, 134

47. YIN, L., Y. LI, J. REN, H. KUWAHARA and D. KUFE (2003): Human MUC1 carcinoma antigen regulates intracellular oxidant levels and the apoptotic response to oxidative stress. J. Biol. Chem. 278, 35458-35464.

48. ZEILLINGER, R., B. SCHMID, D. TONG, B. FASCHING I. SCHIEBL, M. STIMPFL, A. OBERMAIR and S. LEODOLTER (2000): Expression of variant forms of the MUC1 gene correlates with the invasiveness of breast cancer cells. Breast Can. Res. 2, P4-16.

\section{Detekcija polimorfizama jednog nukleotida (SNP-a) u HER2, MUC1, ESR1 i BRCA1 gena povezanih $s$ tumorom mliječne žlijezde kuja}

Juan D. CARVAJAL-AGUDELO, Laura GIRALDO-CHALARCA, Diana M. CORTESMERA, Paula A. OSSA-LÓPEZ, Grupo de Investigación GEBIOME, Departamento de Ciencias Biológicas, Facultad de Ciencias Exactas y Naturales, Universidad de Caldas, Calle 65 No. 26-10 Apartado Aéreo 275 Manizales, Caldas, Colombia; Edwin D. MORALES-ÁLVAREZ, Grupo de Investigación GEBIOME, Departamento de Química, Facultad de Ciencias Exactas y Naturales, Universidad de Caldas, Calle 65 No. 26-10 Apartado Aéreo 275 Manizales, Caldas, Colombia; Fredy A. RIVERA-PÁEZ, Grupo de Investigación GEBIOME, Departamento de Ciencias Biológicas, Facultad de Ciencias Exactasay Naturales, Universidad de Caldas, Calle 65 No. 26-10 Apartado Aéreo 275 Manizales, Caldas, Colombia

Diljem svijeta, tumor mliječne žlijezde kuja (CMC) najčešća je skupina neoplazija kuja te je tri puta učestalija $\mathrm{u}$ pasa nego $\mathrm{u}$ ljudi. U Kolumbiji, CMC je bio druga najčešća vrsta tumora, nakon neoplazija na koži. Nadalje, genetika je jedan od najvažnijih čimbenika uključenih u bilo koju vrstu tumora, a genetska baza ove bolesti održava se kroz linijski uzgoj uslijed promjena alelnih frekvencija, koje se mogu pratiti preko molekularnih markera. Ova studija imala je za cilj detektirati polimorfizme jednog nukleotida (SNP-e) povezane s CMC-om u uzorcima krvi prikupljenih od kuja s CMC-om i zdravih kuja $\mathrm{u}$ veterinarskoj bolnici Diego Villegas Toro Sveučilišta Caldas (Manizales, Kolumbija). Dizajnirali smo početnice uporabom PrimerBLAST i Primer3 te su fragmenti gena HER2, MUC1, ESR1 i BRCA1 pojačani za identifikaciju SNP-a preko mapiranja genoma uporabom preglednika genoma Instituta za genom Sveučilišta Santa Cruz u Kaliforniji (UCSC). Rabili smo genom Canis lupus familaris pasmine bokser [GCF_000002285.3, (CanFam 3.1)] kao referencu za usporedbu fragmenata gena i SNP-a. Povezali smo SNP-e s CMC-om i kontrolnim skupinama testiranjem omjera izgleda (OR) pomoću Fisherovih egzaktnih testova za određivanje povezanosti ili rizika od CMC-a. Detektirali smo dva SNP-a za ESR1, tri za MUC1, šest za HER2 i jedan za BRCA1. MUC1 je bio jedini gen koji je pokazao SNP u regiji egzona što je rezultiralo supstitucijom aminokiseline (Pro>Thr). Nismo pronašli značajne razlike na temelju OR-a, premda je većina SNP-a, izuzev četiri, pronađena u kuja s CMC-om. Prijavljujemo novi molekularni marker za HER2 koji pojačava egzone 25 $26 \mathrm{i}$ introne $24-25$ te naglašavamo važnost provođenja dodatnih studija na MUC1, kao i pojašnjenja uloge introna i izrezivanja $u$ gena kandidata poveznih s CMC-om.

Ključne riječi: genetsko mapiranje, genetska varijacija, intron, neoplazija mliječnih žlijezda, povezanost s SNP-om 